\title{
Badania połączeń spawanych laserem z zastosowaniem mikroskopii akustycznej
}

\author{
Investigation of laser welded joints \\ using acoustic microscopy
}

\section{Streszczenie}

W artykule przedstawiono wyniki badań mające na celu określenie możliwości zastosowania mikroskopii akustycznej do oceny jakości oraz identyfikacji niezgodności wewnętrznych połączeń spawanych techniką laserową. W ramach badań opracowano prototypowe stanowisko do skaningowej mikroskopii akustycznej, posiadające szerokie możliwości adaptacji do geometrii badanego obiektu oraz wyposażone w odpowiednie oprogramowanie zawierające algorytmy analizy i obróbki obrazów typu B-scan or C-scan. Wykorzystując wspomniane stanowisko przeprowadzono badania spoin czołowych, na podstawie których wyznaczono głębokość wtopienia spoiny. Wyniki badań zostały zweryfikowane poprzez badania metalograficzne.

Słowa kluczowe: spawanie laserowe, badania nieniszczące, mikroskopia akustyczna

\section{Abstract}

The article presents chosen results obtained during the investigation of laser welded joints using acoustic microscopy method. For the purpose of the research a prototype setup was built. This system can be easily adjusted to the geometry of the object and is well equipped with appropriate software containing algorithms for the analysis and processing of images such as B-scan or C-scan. Using the research setup the geometry of the weld can be determined, especially in this particular case the depth of the weld penetration. The results were verified by metallographic examination.

Keywords: laser welding, non-destructive testing, acoustic microscopy

\section{Wstęp}

Mikroskopy akustyczne są to urządzenia, których zasada działania opiera się na skanującym ruchu głowicy ultradźwiękowej nad badanym obiektem, który z reguły jest zanurzony w cieczy sprzęgającej. Z tego powodu często nazywane są skanerami ultradźwiękowymi. Są to urządzenia specjalistyczne, często dedykowane dla określonych rodzajów badanych obiektów [1].

Spoiny wykonywane z zastosowaniem techniki laserowej są obecnie często spotykane w przemyśle motoryzacyjnym. Łączone elementy mają tam grubości nieprzekraczające kilku milimetrów. Ponadto geometria uzyskanej spoiny oraz sposób przygotowania elementów do spawania różni się w stosunku do innych, konwencjonalnych metod spawania. Czynniki te powodują, że konieczny jest tu dobór odpowiednich przetworników ultradźwiękowych oraz układów pozycjonujących głowice, które zapewnią wysoką rozdzielczość uzyskanych wyników typu B-scan i C-scan. Jest to ważne z punktu widzenia późniejszej analizy i pomia-

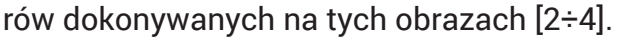

\section{Skanery ultradźwiękowe}

Obecnie niewielu jest producentów tego rodzaju zautomatyzowanych stanowisk badawczych. Mimo tego kinematyka takich urządzeń jest zwykle podobna, oparta na kinematyce robota kartezjańskiego tzn. zapewnia się pozycjonowanie głowicy przez przesuw liniowy w trzech podstawowych osiach X, Y oraz Z. Taka konstrukcja zapewnia odpowiednią sztywność urządzenia co jest istotne z powodu drgań konstrukcji oraz faktu, że badania prowadzi się z dokładnością sięgającą czasami $10^{-5} \mathrm{~m}$.

\section{Stanowisko pomiarowe}

Schemat stanowiska pomiarowego przedstawiono na rysunku 1. W skład stanowiska pomiarowego (rys. 2a) wchodzą:

- karta oscyloskopowa do zastosowań w badaniach ultradźwiękowych o częstotliwości próbkowania $100 \mathrm{MS} / \mathrm{s}$ [5],

- generator o maksymalnym napięciu wyjściowym $350 \mathrm{~V}$,

- zanurzeniowa głowica ultradźwiękowa o wiązce zogni-

Dr inż. Paweł Kustroń, dr inż. Marcin Korzeniowski - Politechnika Wrocławska.

Autor korespondencyjny/Corresponding author. pawel.kustron@edu.pl 
skowanej i częstotliwości $20 \mathrm{MHz}$ (rys. 2b),

- 3-osiowy układ pozycjonujący sterowany silnikami krokowymi (rys. 2a).

Głowica użyta do budowy układu pomiarowego (rys. 2b) jest głowicą zanurzeniową skupiającą fal podłużnych IAHG202 do badań z wysoką rozdzielczością. Dane odebrane przez głowicę są przekazywane do komputera, a następnie analizowane. W miejscach, gdzie zostały ustalone bramki pomiarowe (czerwona i zielona linia na rys. 3a i 3b), program szuka maksimów. Bramka 1 (zielona) jest ustawiana w miejscu występowania sygnału odbitego od powierzchni badanego obiektu. Pozycja bramki 2 (czerwona) jest zależna od położenia maksimum znalezionego w bramce 1 (zielonej). Taki sposób przeprowadzania pomiaru jest często nazywany jako tzw. „surface follower”.

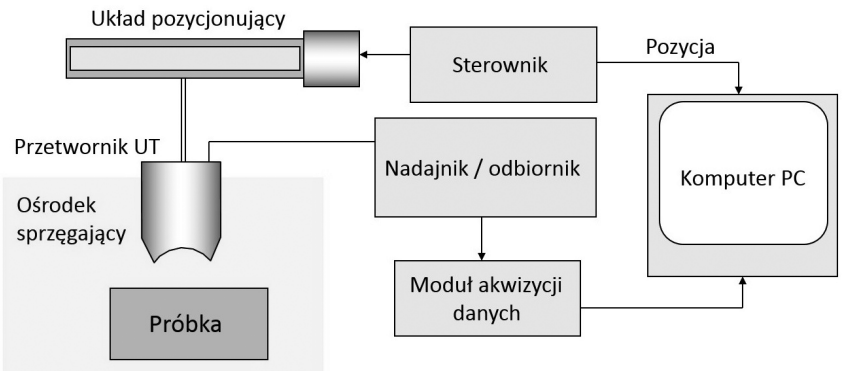

Rys. 1. Schemat ideowy mikroskopu akustycznego

Fig. 1. Schematic diagram of the acoustic microscope
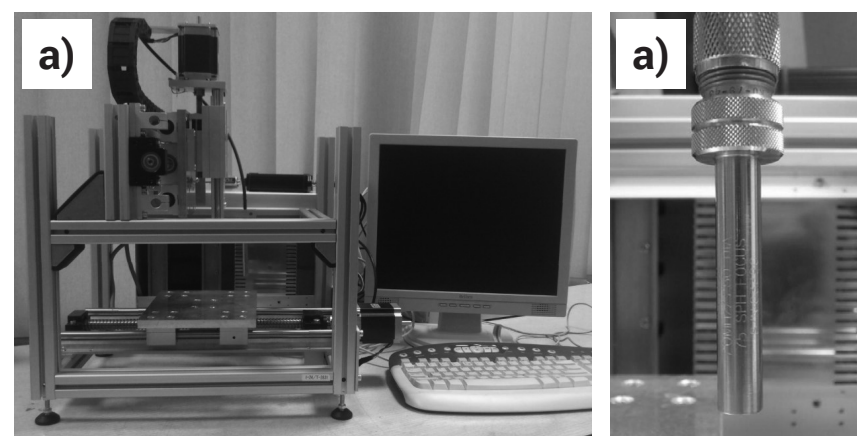

Rys. 2. Stanowisko pomiarowe a) skaner, b) głowica pomiarowa Fig. 2. The measurement system a) scanner, b) ultrasonic head
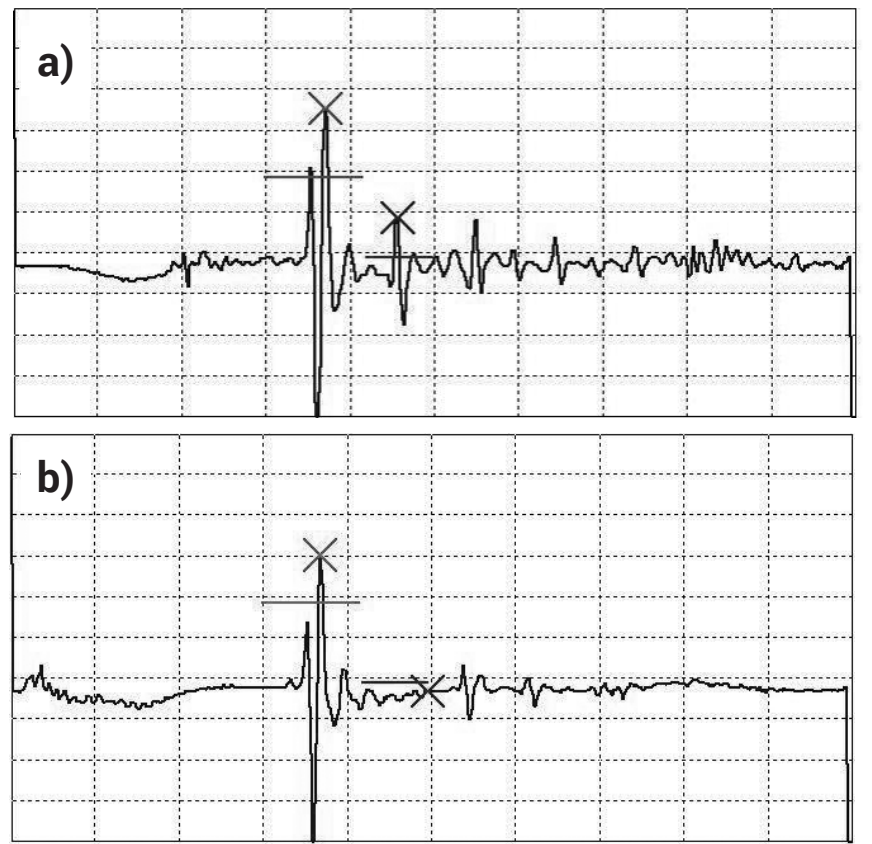

Rys. 3. Sygnały A-scan uzyskane a) poza obszarem złącza b) w obszarze złącza

Fig. 3. A-scan signals received a) outside the joint b) in the joined region
Na rysunku 3a przedstawiono przebieg sygnału (A-scan) pobrany w miejscu gdzie nie występuje połączenie. Świadczy o tym pojawienie się impulsu w bramce nr 2 (czerwonej). Możnatotłumaczyćwystępowaniemnieciągłościmateriału na drodze fali ultradźwiękowej.

$\mathrm{Na}$ rysunku $3 \mathrm{~b}$ przedstawiono przebieg sygnału (A-scan) pobrany w miejscu gdzie występuje połączenie. W tym przypadku w bramce nr 2 (czerwonej) nie występuje odbicie sygnału ultradźwiękowego co potwierdza, iż materiał jest jednorodny lub występuje tu poprawne połączenie spawane.

\section{Wyniki pomiarów}

Badaniom poddano uproszczony element konstrukcji fotela samochodowego spawany laserem. Element złożony jest z dwóch części tj. płaskiej płyty oraz tarczy imitującej wieniec zębaty. $W$ rozważanym przypadku badaniu poddano obszar o wymiarach $37 \times 12 \mathrm{~mm}$ (rys. 4a) z krokiem skanowania $50 \mu \mathrm{m}$. W miejscu styku obu elementów (rys. 4b) występuje spoina czołowa. Rysunek 5 przedstawia obraz typu C uzyskany podczas skanowania elementu z rysunku 4.

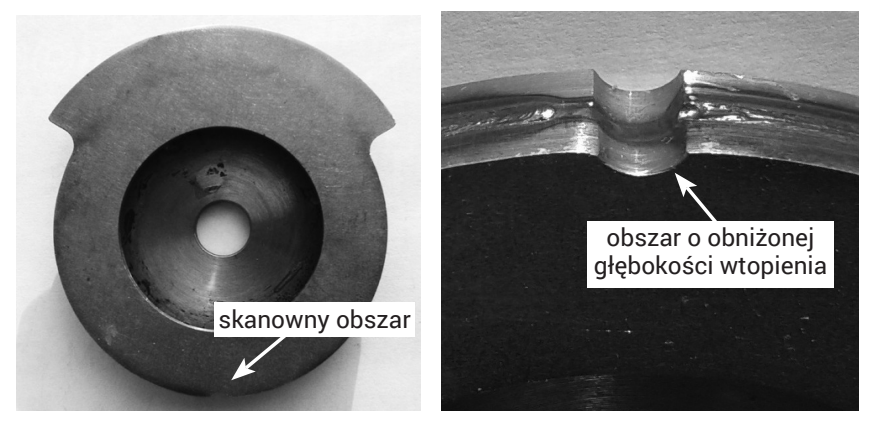

Rys. 4. Badany element a) z oznaczonym obszarem skanowania $(37 \times 12 \mathrm{~mm})$, b) z oznaczonym obszarem o obniżonej głębokości wtopienia

Fig. 4. Tested element a) with marked scanning area $(37 \times 12 \mathrm{~mm})$, b) with marked area of reduced depth of penetration region

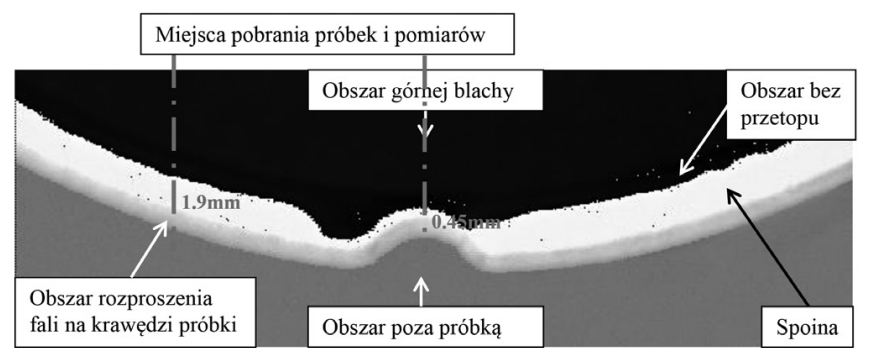

Rys. 5. C-scan wstępnej obróbce z wyselekcjonowanym obszarami złącza Fig. 5. C-scan image after image processing with marked important areas of the joint

Na podstawie przeprowadzonych badań i uzyskanych wyników można w przedstawionym przykładzie wyróżnić strefę spoiny (kolor biały), obszar bez przetopu (kolor czarny), obszar poza próbką (ciemnoszary) oraz obszar rozproszenia fali ultradźwiękowej na krawędzi próbki (jasnoszary). Ponadto na rysunku 5 oznaczono miejsca przeznaczone do oceny w badaniach metalograficznych. Dokonując pomiaru na podstawie obrazu C-scan można stwierdzić, iż głębokość wtopienia w tym miejscu podcięcia próbki wynosi $0,45 \mathrm{~mm}$ natomiast w pozostałym obszarze pomiar wykazał 1,9 mm. Porównując wyniki pomiarów na podstawie obrazów typu B-scan z wynikami badań metalograficznych można stwierdzić, iż uzyskano wysoki stopień zgodności odpowiednich wyników. Wynik badania metalograficznego $\mathrm{w}$ miejscu podcięcia to $0,5 \mathrm{~mm}$ natomiast poza tym obszarem $1,8 \mathrm{~mm}$. 


\section{Podsumowanie}

Zaprezentowane wyniki pomiarów potwierdzają przydatność przedstawionego systemu do oceny jakości połączeń spawanych laserem. W artykule wykazano, iż możliwa jest ocena głębokości wtopienia, poprzez skanowanie elementu w płaszczyźnie prostopadłej do powierzchni lica spoiny. Głównymi ograniczeniami metody są dostęp do badanego miejsca oraz rozpraszanie fali w miejscach załamań na powierzchni badanej próbki. Z tego względu prowadzenie badań zalecane jest dla jedynie od strony płaskiej powierzchni. Zastosowana głowica ultradźwiękowa powinna charakteryzować się jak najmniejszą średnicą ogniska oraz wysokim tłumieniem (krótkim impulsem). Obecnie zastosowano głowicę skupiającą o częstotliwości $20 \mathrm{MHz}$ jednak głowica o wyższej czesiowości (np. 50 MHz) wpłynęłaby pozytywnie na podniesienie rozdzielczości systemu.

Skanowanie powinno odbywać się z rozdzielczością z przedziału od 0,05 $\mathrm{mm}$ do $0,1 \mathrm{~mm}$ w celu zapewnienia jednoznaczności wskazań obrazów typu B i C-scan. Oprogramowanie powinno być wyposażone w odpowiednie algorytmy wykrywające krawędzie badanego obiektu. Jest to konieczne do pomiarów głębokości wtopienia spoin.

\section{Literatura}

[1] Lewińska-Romicka A.: Badania nieniszczące - podstawy defektoskopii, Wydawnictwa Naukowo- Techniczne, Warszawa 2001.

[4] Baranowska J., Garbik M.: Badania ultradźwiękowe, Wydawnictwo Uczelniane Politechniki Szczecińskiej, Szczecin 1999.

[2] Śliwiński A.: Ultradźwięki i ich zastosowania, Wydawnictwa Naukowo-Techniczne, Warszawa 2001.

[3] Jagodziński Z.: Przetworniki ultradźwiękowe, Wydawnictwa Komunikacji i Łączności, Warszawa 1997 